\title{
Rented Room
}

National Cancer Institute

\section{Source}

National Cancer Institute. Rented Room. NCI Thesaurus. Code C159748.

A room within a larger dwelling used as an individual living space in exchange for money. 